\title{
To the Question of the Individual Style of S. Milligan
}

\section{Svetlana Yurievna Kapkova}

\author{
The Department of Foreign Language, Voronezh State Pedagogical University, Voronezh, Russian Federation
}

Email kapk@list.ru

Doi:10.5901/mjss.2015.v6n4s4p215

\begin{abstract}
The article explores the individual style of the writer, analyses some mechanisms of the creation of comic and eccentric effects in poems for children by outstanding English writer S. Milligan and gives the basic characteristics of linguistic means in his poetic works. Comic and eccentric effects in the works of the author are represented as a game with meaning, the interpretation of events or phenomena in completely different forms, leading to a duality of understanding. Polysemy, homonymy, onomatopoeia, unexpected children's interpretations or explanations of what is happening and the game moments are the basis of creating a comic effect in the poems and fairytales for children by S. Milligan. Phonetic puns, illogical things, grotesque, oxymoron, hyperbole, onomatopoeia, impersonation, the creation of new words, chiasm, allusion and antithesis are the main stylistic means in the poetic works of the writer. Moreover, simplicity and euphony are important characteristics of the individual style of S. Milligan. Therefore, various expressive language and visual-graphical means used by the author are connected and aesthetically justified to make the text bright and figurative.
\end{abstract}

Keywords: individual style of an author, modern English children poetry, comic and eccentric effects.

\section{Introduction}

The subject of our scientific interests is modern children English comic and eccentric literature. Our linguistic interests include mechanisms for creating comic and eccentric effects, the study of individual style of modern English writers such as S. Milligan, R. Dahl, J. K. Rowling and F. Symon. In our previous researches we defined that the choice of vocabulary in comic works for children is extremely important from the point of view of artistic and aesthetic values and from the point of view of the perception of the text by the reader, so the writer should consider many factors in his works for children: the age of the readers, the level of their socialization and what children consider funny and comic, as the perception of the text and the picture of the world of the child and the adult are significantly different (Kapkova, 2015).

The study of the individual style of an author covers the study of his use of vocabulary, syntax, phraseology, various forms of speech and of the genre, composition, rhythm and tone of the narrative. The individual style of an author is closely connected with his worldview, his spiritual and creative personality. The complexity and integrity of the spiritual world of the writer find their expression through a variety of expressive forms; also they influence the nature of the image and become one of the traits of an individual style.

\section{Review of the Related Literature}

Any style, including the individual style of an author, is formed under the influence of certain factors. Their combination determines the originality of style (Lotman, 1999). It should be noted that any individual style is not immutable, more than that, it is subjected to numerous changes at different stages of the creative development and spiritual growth of the same writer. The individual style of an author can be studied from different points of view. Some researchers are interested in the selection of vocabulary and stylistic means that perform specific literary and aesthetic functions (Vorozhbitova, 2014). According to Liberman, idiostyle and ideostyle are considered to be different terms (Liberman, 2012). For others it is important to study the structure of sentences, their volume, nature and the ways of combining sentences with one another that, to some extent, reflects a definite connection between the worldview of the writer and his individual style (Brandes, 2004, Klovak, 2014). Moreover, discursive approach is also used to study the individual style of an author and Dawson offers some methodological coordinates for investigating the formal category of narrative voice in a broader discursive context (Dawson, 2012). An explicit idea for the diachronization of narratology was offered by Fludernik (2003). With this term, Fludernik does not mean the historiography of narratology itself, i.e. the history of the development of theoretical concepts, but the history of the actual use made by authors of narrative devices. Some narrative devices have long been 
identified and studied, but narratology has brought together, systematised, and much expanded the number of narrative devices found employed by authors in narrative texts, and thereby opened the way to the study of their use over time. For some group of researchers it is very important to show how emphasis on the message gives way to emphasis on the code or on undermining the code, on the context, on the reader's response, on the relationship between the addresser's and the addressee's shared assumptions and their use of pragmatic principles (Goatly, 2008, Goodman, O'Halloran, 2006, Leech, Short, 2007). Tarasova examines the individual sphere as the mental basis of poetic style in the aspect of its structural organization and typology of basic units. In the course of our work we have studied the following approaches connected with the study of the individual style of the writer:

- Semantic-stylistic approach associated with the names of I.V. Arnold, V.V.Vinogradov, B.A. Larin and others;

- $\quad$ Linguo-poetic approach presented in works by U.N. Karaulov, Y.M. Lotman and others;

- Systemic-structural approach reflected in the research works by Y.M. Lotman, O.V. Sharkhunova and others;

- Communicative approach described in the works by N.S. Bolotova, I.I. Babenko, A. Vasilyev and others (Arnold, 2002). In our research work we adhere to semantic-stylistic approach as the main one considering all the above.

\title{
3. Method
}

In this research we used the method of continuous sampling for the selection of the illustrative examples, stylistic analysis to study the linguistic factors of style formation, linguistic analysis of the text to identify the language characteristics of the individual style of an author, aesthetic analysis for the feasibility of these funds in achieving the comic and eccentric effect in works for children and quantitative analysis to determine the quantitative composition of the investigated phenomena.

Speaking about the analysis of the language of a literary work, first of all we would like to pay attention to the fact that any work is a multi-faceted and complicated phenomenon. Every work has a clear moment that defines its construction, meaning and title. It is difficult enough to distinguish areas of analysis and its components. Stylistic analysis of the language of literary works involves the observation and interpretation of the general tone of the language of the author and the language of his characters and their interactions, the use of stylistic devices to influence the reader in the literary works of different genres (Arnold, 2002). Theme analysis considers the implementation of the language in certain contexts. The most important role in the analysis of the language and style of a literary work performs the consideration of the functional significance of vocabulary, syntax and stylistic means to achieve the author's purpose (Kristal and Deivi, 1980). Thus, we analyze the language and style of literary works in the connection with linguo-aesthetic, literary, extralinguistic and textual analysis of literary works.

Many scientists associate the notion of style with linguistics, aesthetics, literature, art history and other related sciences. In this article we will try to characterize the individual style of the famous English children's writer Spike Milligan. The poems and fairytales by S. Milligan are unique and inimitable. Using the canons of classical poetry for children he created works based on children's emotions, attitudes and behaviour. The difference between S. Milligan's creativity from his predecessors is that his works are written as if not an adult tells a story to a child, but as if a child tries to explain to an adult what and how children feel in a certain situation. Many of his poems became illustrations of children's reasoning. In the example below the child wonders why his elder sister cannot lift him up and he is unable to do that. As a result of his guesses he comes to the conclusion that there is something heavy inside his sister preventing him from lifting her. This naive childish assumption leads to a false logical conclusion:

\author{
My Sister Laura \\ My sister Laura's bigger than me \\ And lifts me up quite easily. \\ I can't lift her, l've tried and tried; \\ She must have something heavy inside (Milligan, 2007).
}

S. Milligan uses imitation of the mentality of small children and subtle knowledge of child psychology in his works. His poems are distinguished by their originality. He wrote in a very witty, elegant and funny manner. If you listen to reading of poems by children, it is easy to discover chant in them. Chant is a distinctive and characteristic feature of children's poetry (Smus, 1989). When the writer heard invented words and funny phrases by his children he gave them the second life to delight the reader's ear. The following poem "Itchy Koo Land" was written due to the phrase, of his seven-year-old daughter Syle: "I wish I was in Itchy Koo Land".

I wish I was in Itchy Koo Land 


\author{
I wish I were in Itchy Koo Land \\ With a little piece of string \\ I'd tie a little bell on it \\ Ting-a-ling-a-ling! \\ I wish I were in Itchy Koo Land \\ A penny in the bank \\ l'd draw it out and spend it all \\ Swank! Swank! Swank! \\ I wish I were in Itchy Koo Land, \\ A pot of purple paint \\ l'd paint myself from head to foot \\ And make poor mummy faint \\ I wish I were in Itchy Koo Land \\ Where adults never ever \\ And children live for ever \\ Ying tong idle i Po(Milligan, 2007).
}

This poem is addressed rather to an adult reader than to a child, the reader can feel nostalgia for his carefree childhood when you do not know the value of money and do not think whether to spend the last coin on sweets or anything else and how it can be very frightening for your mother when you get dirty with a red paint from head to toe. In addition to the word creation ("Itchy Koo Land" and "Ying tong idle I Po") S. Milligan used onomatopoeia in this poem: "Ting-a-ling-a-ling" is an imitation of the sound of a little bell and "Swank! Swank! Swank!" is an imitation of clinking coins.

His inspiration in the creation of poetry for children he received due to the communication with their own children and especially grandchildren. When S. Milligan's daughter was five years old, she said that she wanted to kill the dentist. That phrase inspired the poet to write even to be more correct to describe in a poetic form the full range of children's experiences. Regardless of the age any person had a sense of fear and pain visiting a dentist. It is easy to understand and share the feelings of the child who is there at that moment and who hates even the doctor who is trying to save him from the excruciating pain. The child cannot understand the fact that a painful injection and the drill will save him from pain. His aggressive attitude and desire the death to the doctor, to the nurse, to the injections and to everything connected with the dentist means veiled children's fear. Expressing his fear through aggression the child calms himself and cheers up:

\author{
By Gum \\ Death to the Dentist! \\ Death to his chair! \\ Death to his "this might hurt"! \\ There! There! There! \\ Death to his injections! \\ Death to his nurse! \\ Death to his amalgam! \\ Curse! Curse! Curse! \\ Death to his needle! \\ Death to his drill! \\ Death to his 'open wides"! \\ Kill! Kill! Kill! (Milligan, 2007).
}

It is difficult for an adult to imagine what a busy, intellectually intense and emotional world little children live in. Any little thing can cause a great celebration or, on the contrary, a world tragedy. The author achieves this effect through the naïve and emphatically coloured speech of a child subordinating the meaning, sound and rhythmical acoustic richness of the English language for his goals. Reading the poems written by S. Milligan from the first words you can feel that there is a child in front of you, according to the verbal selection and formation of speech we can even suppose his age or his mood. This is one of the main characteristics of the language and style of S. Milligan. Children reading or listening to his poems can recognize themselves in them or identify their actions with the actions of the characters with their own ones, 
so they enjoy getting great pleasure from those recognition and identification.

Literature researchers usually study poetry examples of the work of one author (Kolesnikova, 1994) and do not pay attention to his vocabulary, figures of speech, size, rhythm and intonation of the particular poetic text, but they are important features in creating a variety of images and sensations. S. Milligan can create the image of his characters not talking about them but describing them through their own speech. In his poems one can hear the voices of serene and naive little children. Coordinated with breathing, intonation and rhythm his works being written in the manner of spoken verse reminiscent vivid and spontaneous children's speech. Through the pattern of his spoken verse the reader can feel how children's thoughts clearly emerge in everything that those thoughts have: consistently or contradictorily, single or diverse. His poetic patterns beautifully convey movement, energy and temperament.

In addition to this characteristic poems by S. Milligan abound with the creation of new words. It even has a poem with the same title: "Onamatapia". The author uses distorted spelling of the term "onomatopoeia", imitating what way some children mispronounce that difficult word.

\author{
Onamatapia! \\ Thud- Wallop - CRASH! \\ Onamatapia! Snip-Snap-GNASH! \\ Onamatapia! Wack-thud-BASH! \\ Onamatapia! Bong-Ting-SPLASH! (Milligan, 2007).
}

The combination of the words imitates the sounds of blows. Moreover, the author illustrated his poem with a funny picture himself: a thick musician in a full dress uniform hits himself on his huge belly with the drum sticks producing the sounds "Boom! Boom! Boom!"

Like A. Lear, S. Milligan also illustrated his poems and stories himself. Sometimes his illustrations help in decoding the subtext inherent in the poem, sometimes even strengthening the comic effect of the content.

In the example below the author parodies through the grammatical structure and the rhythmic pattern of the first stanza a well-known and popular in Europe and America poem. It is a famous Christmas song Jingle, Bells

\begin{tabular}{|c|c|}
\hline Teeth & Jingle, Bells \\
\hline English Teeth, English Teeth! & Jingle, bells, jingle bells! \\
\hline Shining in the sun & Jingle all the way! \\
\hline A part of British heritage & Oh what fun it is to ride \\
\hline Aey, each and every one. & In one-horse open sleigh. \\
\hline English Teeth, Happy Teeth! & ng through the snow \\
\hline Always having fun & In one horse open sleigh \\
\hline Clamping down on bits of fish & O'er the fields we go \\
\hline And sausages half done. & Laughing all the way. \\
\hline English Teeth, HEROES' Teeth! & Bells, on bob-tail ring, \\
\hline Hear then click! and clack! & Making spirits bright. \\
\hline Let's sing a song of praise to them - & What fun it is to ride \\
\hline $\begin{array}{l}\text { Three cheers for the Brown Grey and } \\
\text { Black (Milligan, 2007). }\end{array}$ & A sleighing song tonight \\
\hline
\end{tabular}

In this poem comic effect is based on several ironic hyperboles. For example, in the first stanza the author says that British teeth are a part of British heritage and in the third stanza that some songs of praise should be sung to them. The combination of hyperbole and impersonation - teeth have fun munching fish and sausages always having fun clamping down on bits of fish and sausages half done - we can see in the second stanza. There is another case of impersonation - Happy Teeth - in the second stanza. In the third stanza, in addition to hyperbole, the author uses onomatopoeia - the imitation of the sound of the teeth while chewing: click and clack. More than that the comic effect is enhanced with the help of graphic presentation: the word heroes is written in capital letters. Thus the importance of belonging of the teeth to the heroes of the English nation is underlined a mocking way. And in the illustration of the author you can see a knight with a smile of all thirty-two teeth riding on a toothy horse. In one hand the knight holds a flag and in the other hand he has a shield. Either the flag or the shield shows the emblem in the form of large false teeth. 


\section{Results}

Speaking of S. Milligan's literary works in general it should be noted that his poetry and prose have become the inheritance of English children literature and entered the world of classic literature. The language and style of the works S. Milligan differ from the language and style of his colleagues and predecessors, the representatives of the school of absurdity. His poetry is characterized by a diverse of parallelism, repetitions, puns, onomatopoeias, antithesis and numerous euphonic elements such as epiphora, various types of anaphora, refrains, assonance and alliteration. The writer enjoys using sharp transitions. Asyndetically clutters create the impression of a reckless, spontaneous movement of thoughts and emotions that, as a rule, is a characteristic of children's speech. The abundance of short exclamatory sentences indicates his works as saturated emotionally and expressive ones.

S. Milligan wrote many of his poems in speech and rhetorical verses, some of them are children's reasoning about natural phenomena and the behavior of adults but almost all of them are written as if through the prism of the child's view of the world. Having heard the words and funny phrases invented by his children S. Milligan gave them their second life in his works. He admired and wrote down the words, created by his children or the children's interpretation of unknown words to them. Most of his poems were written to amuse the reader; some of the poems were the result of how the children were speaking.

Snatched from the spoken language the children's slips of the tongues or new words reflect the feelings of the child in the world around him, and the author subtly and accurately uses those words in his poems, revealing the world of emotional experiences of the child, returning the adult reader in the forgotten world of childhood. Each 'childish' word brings something special into the structure of measured poetic speech, into its intonation and sound coloration. In some new combinations definite new shades of meaning appear and the reader enjoys the process of understanding such new meaning with happiness and satisfaction. S. Milligan dedicated his poems not only to young readers, but as reading to the whole family. S. Milligan presented comic and eccentric effects through the language game, generating unrestrained joy and mischievous fun. Comic and eccentric effect in the works of the studied author is represented as a game with meaning, the interpretation of events or phenomena in completely different forms, leading to a duality of understanding. Polysemy, homonymy, onomatopoeia, unexpected children interpretations or explanations of what is happening and, of course, the game moments are the basis of creating a comic effect in the poems and fairytales for children by S. Milligan.

\section{Discussion}

During our research we analyzed 94 poems for children and identified 26 different stylistic means used to achieve a necessary comic and eccentric effect. Phonetic puns, illogical things, grotesque, oxymoron, hyperbole, onomatopoeia, impersonation, the creation of new words, chiasm, allusion and antithesis are the main stylistic means in the poetic works of the writer according to the frequency of use. Having considered the author's style from the standpoint of the functioning of the occasional linguistic means in the text we share the conception by Dawson who states that individual style is not so much irrelevant as it is methodologically challenging for narrative theory (Dawson, 2013).

In addition to expressiveness simplicity and euphony are important characteristics of an individual style of $\mathrm{S}$. Milligan as an author. Therefore, various expressive language and visual-graphical means used by the author are connected and aesthetically justified to make the text bright and figurative. Our results indicate the use of evaluative adjectives and vocabulary as a reflection of the individual style of an author. A similar idea can be found in works by Plankina as epithets being carriers of evaluative information in the text reflect the opposition friend or foe (Plankina, 2014).

Having compared our results with the positions of some scientists (Robinson, 1985, Camlot, 2008) we can confirm that the author's modality is one of the components of the style and manifestation of the writer's individuality, his emotional attitude and point of view. It should be noted that the material about the individual style of an author is extensive for study, so this theme is open for further research.

\section{Acknowledgements}

The research effort is funded by grant "Peculiarities of the style of modern English writers" from Voronezh State Pedagogical University, Russia (monitored by Dr. V.A Khonik and Dr. S.I. Filonenko). The author is also thankful to Dr. S.S. Berkner for his contribution in many discussions and exchange of ideas and support. No doubt, this manuscript would not have been possible without the contributions of all the authors mentioned on its pages. Finally, the author would like to thank her university colleagues for their support, encouragement and interest in this work. 


\section{References}

Arnold, I.V. (2002). Stilistika sovremennoho angliiskoho yazyka. [Stylistics of contemporary English language] Moscow: Nauka [in Russian].

Brandes, M.P. (2004). Stylistic analysis (in German language). (3d. ed.). Moscow: Progress-traditsiia: INFRA-M [in Russian].

Camlot, J. (2008). Style and the Nineteenth-century British Critic: Sincere Mannerisms, Ashgate Publishing, Ltd.

Dawson, P. (2012). Real authors and real readers: Omniscient narration and a discursive approach to the narrative communication model. Journal of Narrative Theory, Vol. 42, 1, 91 - 116. Retrieved from http://dx.doi.org/10.1353/jnt.2012.0010

Dawson, P. (2013). Style, the Narrating Instance, and the 'Trace' of Writing. Style, Vol. 47, 4, 466 - 489.

Fludernik, M. (2003). The Diachronization of Narratology. Narrative Vol. 11, 3, 331-348

Goatly, A. (2008). Explorations in Stylistics, Equinox.

Goodman, S., \& O'Halloran, K., (2006). The Art of English: Literary Creativity, Basingstoke: Macmillan.

Leech, G.N. \& Short, M. (2007). Style in Fiction: A Linguistic Introduction to English Fictional Prose. Pearson Ltd.

Kapkova, S.Ju. (2015). Analiz leksicheskih osobennostei perevoda proizvedenii R. Dalia dlia detei. [The analysis of lexical peculiarities of the translation of the works for children by R. Dahl]. Filolohicheskie nauki. Voprosy teorii i praktiki - Philological science. The theory and practice, Vol. 2, 3, 105-109. [in Russian].

Klovak, E.V. (2014). Avtorskaia modalnost kak odin iz komponentov idiostilia [Author's modality as one of the components of idiostyle in Russian].Vestnik TvGU seriia Filolohiia 2, 47-53 [in Russian].

Kolesnikova, O.I. (1994). Zametki o iazyke poezii dlia detei. [Notes on the language of poetry for children]. Russkii jazik v shkole - The Russian language at school, 4, 114-116. [in Russian].

Kristal, D., \& Deivi, D. (1980). Stilisticheskij analiz. [Stylistic analysis]. Novoe v zarubezhnoi lingvistike - New in foreign linguistics, 148171 [in Russian].

Liberman, Ja.L. (2012). Idiostil i ideostil, kak obekty hudozhestvennoho perevoda [Idiostyle and ideostyle as objects of literary translation]. Filologiia i literaturovedenie. - Philology and literary study. 5 Retrieved from http://philology.snauka.ru/2012/05/240 [in Russian].

Lotman, Yu.M. (1999). O poetah i poezii: analiz poeticheskoho teksta. Statii i issledovaniia. [On poetry and poets: the analysis of a poetic text. Articles and research works]. St Petersburg: Iskusstvo-SPB [in Russian].

Milligan, S. (2007). A Children's Treasury of Milligan. London: Virgin Books.

Robinson, J.M. (1985). Style and Personality in the Literary Work. The Philosophical Review. Vol. 94, 2, 227-247.

Plankina, R.M. (2014). Otsenochnaia leksika kak otrazhenie idiostilia of M.Mitchell (na primere oppozitsii «svoi-chuzhoi») [Evaluative vocabulary as a reflection of idiostyle of $\mathrm{M}$. Mitchell (on the example of the opposition "friend or foe")]. Filologiia i kultura Philology and culture. 1, 83-86. Retrieved from http://cyberleninka.ru/article/n/otsenochnaya-leksika-kak-otrazhenie-idiostilya-mmitchell-na-primere-oppozitsii-svoy-chuzhoy [in Russian].

Smus, M.A. (1989). Rol foneticheskoi struktury poeticheskoho teksta v sozdanii ritmicheskoho dvizheniia (eksperimentalnofoneticheskoe issledovanie (na materiale Nursery Rhymes). [The role of the phonetic structure of a poetic text in the creation of a rhythmic movement (experimental phonetic study on the material of Nursery Rhymes)]. Extended abstract of candidate's thesis. Moscow [in Russian].

Tarasova, I.A. (2012). Poeticheskii idiostil v kognitivnom aspekte [Poetic idiostyle in the cognitive aspect]. Moscow: Flinta [in Russian].

Vorozhbitova, A.A., \& Druzhinina, V.V. (2014). Lingvoritoricheskie parametry idiostilia kak vyrazhenie mentaliteta iazykovoi lichnosti uchenoho (A. F. Losev) [Linguistic and rhetorical options of style as an expression of the mentality of the language personality of the scientist (A. F. Losev)]. Moscow: Flinta [in Russian]. 